\title{
Thesis on the Rearrangement of the Reclamation and Post-Mining Supervision System According to Law No. 4 of 2009 Concerning Mineral and Coal Mining
}

\author{
Sucy Delyarahmi; Sukanda Husin; Remrandt \\ Faculty of Law, Andalas University, Padang, Indonesia
}

http://dx.doi.org/10.18415/ijmmu.v6i4.961

\begin{abstract}
This study aims to explore and find future concepts and ideas for the reclamation and post-mining supervision system so that it can run effectively. This study applies non-doctrinal-qualitative and normative juridical approaches. In addition, the data was collected through studies of primary, secondary and tertiary legal materials. The results of the study show that in relation to the reclamation and postmining guarantee funds, Mining License and Special Mining License holders place reclamation guarantee funds in advance in accordance with the work plan and annual budget of a maximum of 30 days after the work plan is approved. Furthermore, funds are placed at state banks in the form of time deposits on behalf of the Directorate General/ Governor in accordance with the reclamation schedule. Then, the implementation of reclamation and post-mining supervision is still not optimal because the readiness of supervisors is inadequate to conduct supervision activities with a limited number of supervisors. Thus, this study recommends to revise Law No. 4 of 2009 concerning Mineral and Coal Mining by strengthening the articles relating to reclamation and post-mining supervision, increasing more effective coordination between related agencies in supervision activities by forming a Supervisory Agency if necessary, increasing the quantity and quality of mine supervisors or inspectors, and strengthening the role of the association of mining business actors so that they become a bridge of compliance in the implementation of reclamation and post-mining carried out by business actors.
\end{abstract}

Keywords: Guarantee Funds; Post-Mining; Reclamation; Supervision

\section{Introduction}

Indonesia is country rich in minerals and coal. Mineral and coal reserves in the mine owned by PT Indonesia Asahan Alumunium (Persero) or Inalum alone reached US \$ 469.7 billion, equivalent to IDR $6,528.83$ trillion (assuming US \$ $1=$ IDR 13,900). ${ }^{1}$ Still at Inalum's mine, nickel reserves reached 3 million tons, coal reached 3.3 billion tons, bauxite reached 7.3 million tons, tin 377 reached thousand

1 CNBC Indonesia,2018.Wow!Inalum Mineral and Coal Reserves are IDR 6,528 trillion.Accessed from https://www.cnbcindonesia.com/news/20180605100554-4-17862/wow-nilai-cadangan-mineral-dan-batu-bara-inalum-rp-6528-t 
tons, and silver 6,181 reached tons. Meanwhile, the amount of potential reserves could reach US \$1.07 trillion. $^{2}$

There has been an increase in the contribution of the mining sector to Gross Domestic Product from 2015 to 2018. However, the issue that has always evolved from increasing the quantity of mining is the ecological impact resulting from that activity. Environmental activists in particular always question the company's responsibility for the ecological impacts resulting from mining.

In fact, the Indonesian Forum for the Environment (Walhi) states that Indonesia is in an ecological emergency. ${ }^{3}$ Put simply, according to Walhi, this can be defined as a situation or precarious situation due to environmental damage. This, according to Walhi, is based on monopolistic activities over the control of natural resources that are not environmentally friendly so that it has an impact on the loss of community access to livelihoods. According to Walhi, the mental revolution launched by the government has not yet succeeded in completely releasing the people from the attempts to silence, criminalize, violence and seize their rights. The portrait caused an imbalance in space control. Meanwhile, law enforcement is still focused on investment services.

In the Walhi record, permits from around 159,178,237 hectares of land had been plotted. This area is equivalent to $30.65 \%$ of Indonesia (land and sea). As an illustration, according to Walhi, the land area of Indonesia is around 191,944,000 hectares and the sea area reaches 327,381,000 hectares. Licensed lots are scattered as much as $59.77 \%$ on land and $13.57 \%$ at sea.

From the land tenure, it was noted that there were 302 environmental and agrarian conflicts and 163 people were decriminalized during 2017. The data came from 13 (thirteen) provinces covering Aceh, West Sumatra, Riau, Jambi, Bengkulu, Lampung, DKI Jakarta, West Java, Central Java, East Java, East Borneo, South Sulawesi and Papua. In addition, based on data from the National Disaster Management Agency (BNPB), there are 2,175 disaster incidents in Indonesia. Based on that data, 99.08\% is an ecological disaster, one of which is caused by the impact of mining activities. Based on the previous explanation, the utilization of natural resources through mining activities cannot be separated from problems that harm the surrounding environment. This is because mining is often ambiguous and tends to violate the law. Thus, it has an impact on environmental damage. Therefore, mining activities should be a concern of the government.

Regarding mining, the author would like to examine specifically about mineral and coal mining. This mineral and coal mining has been regulated in Law No. 4 of 2009 concerning Mineral and Coal Mining. In the preamble of the Law, the legislators stated that the minerals and coal contained in the Indonesian mining jurisdiction constitute non-renewable natural resources as a gift from God, who has an important role in fulfilling the lives of many people. Furthermore, land has an important role in providing tangible added value to national economic growth and sustainable regional development; according to Article 1 number 3 of the Law of the Republic of Indonesia No. 32 of 2009 concerning Environmental Protection and Management. Thus, the management of resources must be controlled by the state to provide tangible added value to the national economy in an effort to achieve prosperity and welfare of the people in a just manner.

Law No. 4 of 2009 concerning Mineral and Coal Mining consists of 26 Chapters and 175 Articles. There are several important points regulated in this Law; for instance, related to the management authority of mineral and coal mining. Furthermore, it regulates mining business permits. The latter is

\footnotetext{
${ }^{2}$ Loc. Cit.

${ }^{3}$ Mongabay, 2018. Walhi: Indonesia's Condition is Still in an Ecological Emergency. Accessed from https://www.mongabay.co.id/2018/04/24/walhi-kondisi-indonesia-masih-darurat-ekologis/
} 
related to sanctions for administrative or criminal violations. In this study, the author will not describe mining in general. However, it only describes matters relating to reclamation and post-mining in mineral and coal mining.

According to the provisions of Article 1 number 1 of Law No. 4 of 2009 concerning Mineral and Coal Mining, the many benefits of mining activities must absolutely be accompanied by reclamation and post-mining obligations; Article 1 number 26 of Law No. 4 of 2009 concerning Mineral and Coal Mining. Article 1 number 27 of Law No. 4 of 2009 concerning Mineral and Coal Mining. Article 2 Government Regulation of the Republic of Indonesia No. 78 of 2010 concerning Reclamation and Postmining.

Regarding reclamation and post-mining, the company is required to pay reclamation and postmining guarantee funds. This is in line with Article 29 paragraph (1) of Government Regulation of the Republic of Indonesia No. 78 of 2010 concerning Reclamation and Postmining. Article 1 number 16 Regulation of the Minister of Energy and Mineral Resources No. 7 of 2014 concerning Implementation of Reclamation and Post-Mining in Mineral and Coal Mining Business Activities; Furthermore, it also includes Article 1 number 17 of the Regulation of the Minister of Energy and Mineral Resources No. 7 of 2014 concerning the Implementation of Reclamation and Post-Mining in Mineral and Coal Mining Business Activities.

Although it has been regulated, this regulation has not been implemented maximally by employers, because supervision in the implementation of reclamation and post-mining is very weak. The level of compliance of Mining License holders to reclamation and post-mining obligations is also still low. ${ }^{4}$ The Directorate General of Mineral and Coal at the Ministry of Energy and Mineral Resources stated that of around 50\% Mining License holders, only $2 \%$ had fulfilled their reclamation and post-mining obligations in 2018 from the conditions in September 2017 at 48\%. The area of land that must receive reclamation and post-mining obligations is quite extensive. For instance, in Bangka Belitung Province, the area of post-mining land reaches 200,000 ha. ${ }^{5}$ For another example, from just one company such as PT ANTAM, the area of land that needs reclamation in 2015 reached 5,748 ha. ${ }^{6}$ Another example in Samarinda, there are 232 abandoned mining pits. The remaining mining pits are also found in Kutai Kartanegara, East Kutai, and Berau. ${ }^{7}$

Thus, based on the explanation above, the author is interested in discussing and researching on the Reorganization of the Reclamation and Post-Mining Supervision System According to Law No. 4 of 2009 concerning Mineral and Coal Mining.

\section{Research Method}

Basically, research is a stage to look for a truth. Therefore, it will answer the questions that arise about an object of research. Research is a basic means for developing science because it is carried out systematically, methodologically and analytically to draw conclusions. This legal research is a normative legal research.

\footnotetext{
${ }^{4}$ Bisnis.com, 2018. Reclamation \& Post-Mining Guarantees Are Still Low. Accessed from https://ekonomi.bisnis.com/read/20180114/44/726374/jaminan-reklamasi-pascatambang-masih-rendah

${ }^{5}$ Ministry of Environment and Forestry, 2018. Light up the Post-Mining Land in Bangka Belitung Province. Accessed from http://www.menlhk.go.id/berita-10841-hijaukan-lahan-pasca-tambang-di-provinsi-bangka-belitung.html

${ }^{6}$ PT ANTAM, 2016. Biodiversity. Accessed from http://www.antam.com/index.php?option=com_content\&task=view\&id=428\&Itemid=211\&lang=i

${ }^{7}$ Tempo, 2018. Reclamation of Mining Pit. Accessed from https://kolom.tempo.co/read/1094037/reklamasi-lubang-sisatambang/full\&view=ok.
} 
According to F. Sugeng Istanto, legal research is research that is applied or treated specifically in the science of law. ${ }^{8}$ In line with the views of F. Sugeng Istanto, in a book entitled Legal Research, Moris L. Cohen mentioned that "legal research is the process of finding the law that governs activities in human society". ${ }^{9}$ Furthermore, Cohen stated that "it involves locating both the rules which are enforced by the states and commentaries which explain or analyze these rules". ${ }^{10}$ Furthermore, Peter Mahmud Marzuki quoted two Belgian scholars Jan Gijssels and Mark Van Hoecker who explained that legal research is a process of finding legal rules, legal principles and legal doctrines to answer legal issues. ${ }^{11}$

This is a descriptive diagnostic study. Diagnostic means a study that intends to investigate and obtain information about a phenomenon. ${ }^{12}$ In this case, it is related to the Reclamation Supervision and Post-Mining Supervision according to Law No. 4 of 2009 concerning Mineral and Coal Mining. Meanwhile, descriptive research is intended to provide as much detailed data as possible about the research problem ${ }^{13}$ as well as to provide a complete picture related to the Reclamation and Post-Mining Supervision Arrangement According to Law No. 4 of 2009 concerning Mineral and Coal Mining.

This study uses a non-doctrinal-qualitative research approach and a normative juridical research approach. Non-doctrinal-qualitative research approach is a research approach that starts from the observation of social realities and then is placed as a general proposition alias major premise reinforced by in-depth interviews with informants related to these realities. Meanwhile, the approach in normative research aims to examine the principles of law, legal synchronization, legal history, and legal comparison. ${ }^{14}$ In order to collect the legal materials, the following approaches were carried out: ${ }^{15}$

1. Statute approach

2. Case approach

3. Conceptual approach

4. Historical approach

All useful data in this paper were obtained through documentary study or documentary material. It is a data collection technique that was carried out by studying library materials or written data, especially those relating to the problem to be discussed. It was also carried out through interviews with experts or expertise who know and deal with the problems that the authors carefully to obtain a deeper explanation. Then, the authors analyze the contents of the data. ${ }^{16}$ All data that has been obtained will be processed through the editing process. The data that has been obtained will not be entirely taken and inputted. This study will only choose legal materials that are related to research problems to obtain more structured legal materials. ${ }^{17}$

\footnotetext{
${ }^{8}$ F. Sugeng Istanto, 2007. Legal Research, CV Ganda, Yogyakarta, page 29., quoted from Saldi Isra, 2009. Shifts to the Legislative Function in the Indonesian Government System After Amendment to the 1945 Constitution, Dissertation for Postgraduate Program, Faculty of Law, Gadjah Mada University, Yogyakarta, page 141, in Saldi Isra, 2014. Recruitment and Appointment System of Supreme Court Justices and Constitutional Justices in the Conception of the Rule of Law, Research on the National Legal Development Agency (BPHN) in 2014, Jakarta, page 10.

${ }^{9}$ Peter Mahmud Marzuki, 2007. Legal Research, CV. Ganda, Yogyakarta, $3{ }^{\text {rd }}$ Print, Pranada Media Group, Jakarta, page 137

${ }^{10}$ Ibid., page 37.

${ }^{11}$ Ibid., page 29.

${ }^{12}$ Soerjono Soekanto, 2007. Factors Affecting Law Enforcement, Publisher PT Raja Grafindo Persada, Jakarta, page 10.

${ }^{13}$ Ibid., page 11.

${ }^{14}$ Soerjono Soekanto, Op. Cit., page 50.

${ }^{15}$ Peter Mahmud Marzuki, Op. Cit., page 133.

${ }_{17}^{16}$ Bambang Sunggono, Op. Cit., page 38.

${ }^{17}$ Ibid., page 39.
} 


\section{Future Ideas and Concepts on Reclamation and Post-Mining Supervision}

To put forward constructive ideas for reclamation and post-mining supervision, the existing conditions of reclamation and post-mining supervision need to be identified and explained in advance. In order to identify the existing conditions, this study uses a conceptual framework in the form of New Institutional Economics and Sociology (NIES) theory proposed by Victor Nee. ${ }^{18}$

As can be seen in the following figure, the NIES model shows a causal mechanism that operates in both directions; from macro to micro and from micro to macro. This causal mechanism is used to analyze the structure of organizational and corporate incentives as well as regulations governing property, market, and enterprise that are integrated with formal and informal rules in the Meso (organizational) and Micro (social groups and individuals) levels. Thus, each order has an analysis of different causal relationships with the institutions involved in it.

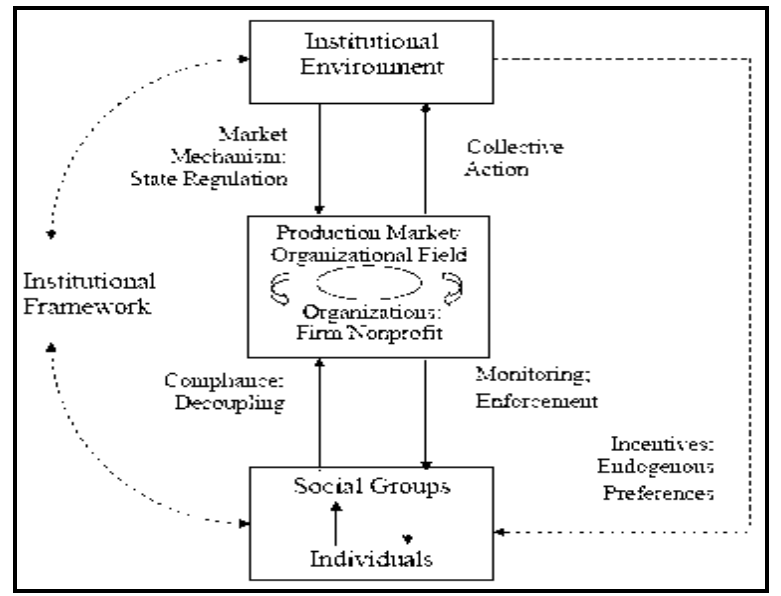

Figure 1. New Institutional Economics and Sociology (NIES) Model

At the macro level, there is an institutional environment that has a role in terms of regulation. This role becomes the government's authority in the life of the nation and state. However, in carrying out this role, there are influences from the environment as explained by Winarno regarding public policy. According to him, public policy is a policy developed by government institutions and government officials who are influenced by non-government actors and factors. ${ }^{19}$ Winarno's explanation is similar to Eyeston's, who explained that public policy can be defined as the relationship between government and the environment. ${ }^{20}$

Although the process gets influence from the environment, but, when something has been determined to be a government policy, the parties who become the object of the policy must obey the rules in the policy. Dye explained that public policy is whatever the government chooses to do and not do. ${ }^{21}$ In relation to the NIES theory, the government policy applies to parties at the Meso and Micro level.

There is a role played by parties at the Meso level. In the context of NIES, the roles are collective action and monitoring \& enforcement. Regarding collective action, Olson explained that the role was

\footnotetext{
${ }^{18}$ Nee, Victor, 2003. The New Institutionalism in Economics and Sociology. Center of Study Economy and Society, Vol. 4, page3

${ }^{19}$ Winarno, Budi. 2005. The Theory and Process of Public Policy, Medpress, Yogyakarta, page 20.

${ }^{20}$ Eyeston, Robert. 1971. The Threads of Policy: A Study in Police Leadership, Bobbs Merril, Indiana Polis, page 112.

${ }^{21}$ Dye, Thomas R. 1975. Understanding Public Policy, Printice-Hall $2^{\text {nd }}$ ed, Englewood Cliff, N. J., page 34
} 
related to interest groups. Referring to Olson, important factors that determine the success of collective action are the size, homogeneity, and goals of the related group. Apart from the interests held by interest groups, referring to Ostrom in Nabli and Nugent, this collective action is designed to produce cooperative solutions so that it can solve difficult problems and achieve efficiency in the use of resources. Regarding monitoring \& enforceement, referring to the opinion of Gary Miller, Ménard and Shirley ${ }^{22}$ explained that this was related to the principal agent theory. In relation to the theory of principal agents and NIES, the parties at the Meso level are the principal, while the parties at the Micro level are the agents.

According to NIES theory, there is decoupling and compliance at the Micro level. Regarding decoupling, Nee defined it as a mismatch between formal policy practices in the field. Then, compliance is related to efforts that can be made so that formal legal arrangements can be applied in accordance with what is expected. Compliance will occur if the actors who are policy makers always make the real situation on the field a consideration in taking formal policy.

The Micro level relates to market organizations. In a pure market transaction, there is no authority relationship between the two parties and there is no central structure. The price system provides "high powered" incentives for both parties who adapt to changing market conditions. In a market with a large number of transaction actors, partner identity is irrelevant and partner selection is not required. In "unclear" markets, there is no interdependence relationship between partners, so transaction costs can be ignored.

Due to market failures and transaction costs, the hierarchy will replace the market. Interdependence causes partner identity to be important so it creates a need for partner selection mechanisms. As a company that grows in scale and scope, it requires a general staff and administrative control to coordinate activities within the company. Administrative control mechanisms include systems planning, information sharing, integration, monitoring and performance evaluation.

In the perspective of transaction costs, markets and hierarchies are polar models of governance in a unidimensional unity, whereas "hybrid models display intermediate values". In particular, this hybrid form is characterized by semi-strong incentives, mid-level administration apparatus featuring semi-strong adaptations of both types and developing semi-legalistic contract legal regimes. ${ }^{23}$

Ménard sifts through a lot of literature on hybrid arrangements including networks, supply chains, franchise agreements, partnerships and cooperatives. ${ }^{24} \mathrm{He}$ identified three common characteristics: union, contracting and competition. He argues that there is indeed a great diversity of agreements between autonomous entities legally in conducting joint business, adjusting with each other with a little help from the price system, and sharing or exchanging technology, capital, products, and services. Ménard classified various hybrid arrangements in four general configurations, consisting of: trust, relational networks, leadership and formal governance which are defined as the middle model between market and hierarchy. ${ }^{25}$

Regarding the reclamation and post-mining supervision mechanism, the Macro level shows the existence of a linkage in the form of regulations relating to the reclamation and post-mining supervision including Law No. 4 of 2009 concerning Mineral and Coal Mining, Law No. 32 of 2009 concerning Environmental Protection and Management and Derivative Regulations, Government Regulation No. 55 of 2010 concerning Development and Supervision of the Management of Mineral and Coal Mining

\footnotetext{
22 Ménard, Claude, 2004. The Economics of Hybrid Organizations, Journal of Institutional and Theoretical Economics (JITE)/Zeitshrift für die gesamte Staatswissenschaft, Vol. 160, No. 3, page 345-376.

${ }^{23}$ Williamson, Oliver E.1975. Markets and Hierarchies: Analysis and Antitrust Implications, The Free Press, New York, page 28.

24 Ménard, Claude, 2004. The Economics of Hybrid Organizations, Journal of Institutional and Theoretical Economics (JITE)/Zeitshrift für die gesamte Staatswissenschaft, Vol. 160. No. 3, page 345-376.

${ }^{25}$ Ibid., page 347.
} 
Business Management, Government Regulation No. 78 of 2010 concerning Reclamation and Postmining. At this Macro level, the parties that play a role are the House of Representatives of the Republic of Indonesia and the President. The two institutions are actors involved in determining the direction of the reclamation and post-mining supervision policies in the form of laws and regulations that are the rights of the president.

At the Meso level, governance institutions or structures in reclamation and post-mining supervision include the Ministry of Energy and Mineral Resources, the Ministry of Environment and Forestry, and local governments. At this Meso level, these agencies have derived rules and Standard Operating Procedures to supervise reclamation and post-mining. An example of a derivative rule at the Meso level is Minister of Energy and Mineral Resources Regulation No. 26 of 2018 concerning Implementation of Good Mining Rules and Supervision of Mineral and Coal Mining, and Minister of Energy and Mineral Resources Decree No. 1827/K/30/MEM/2018 of 2018, Appendix VI concerning Guidelines for Implementing Good Mining Engineering Rules.

At the Micro level, it involves parties from mineral and coal mining businesses. The parties carry out interactions and transactions. In the context of supervision, the parties at the Micro level are the objects of supervision at the Meso level. The following figure shows the relationship of the parties.

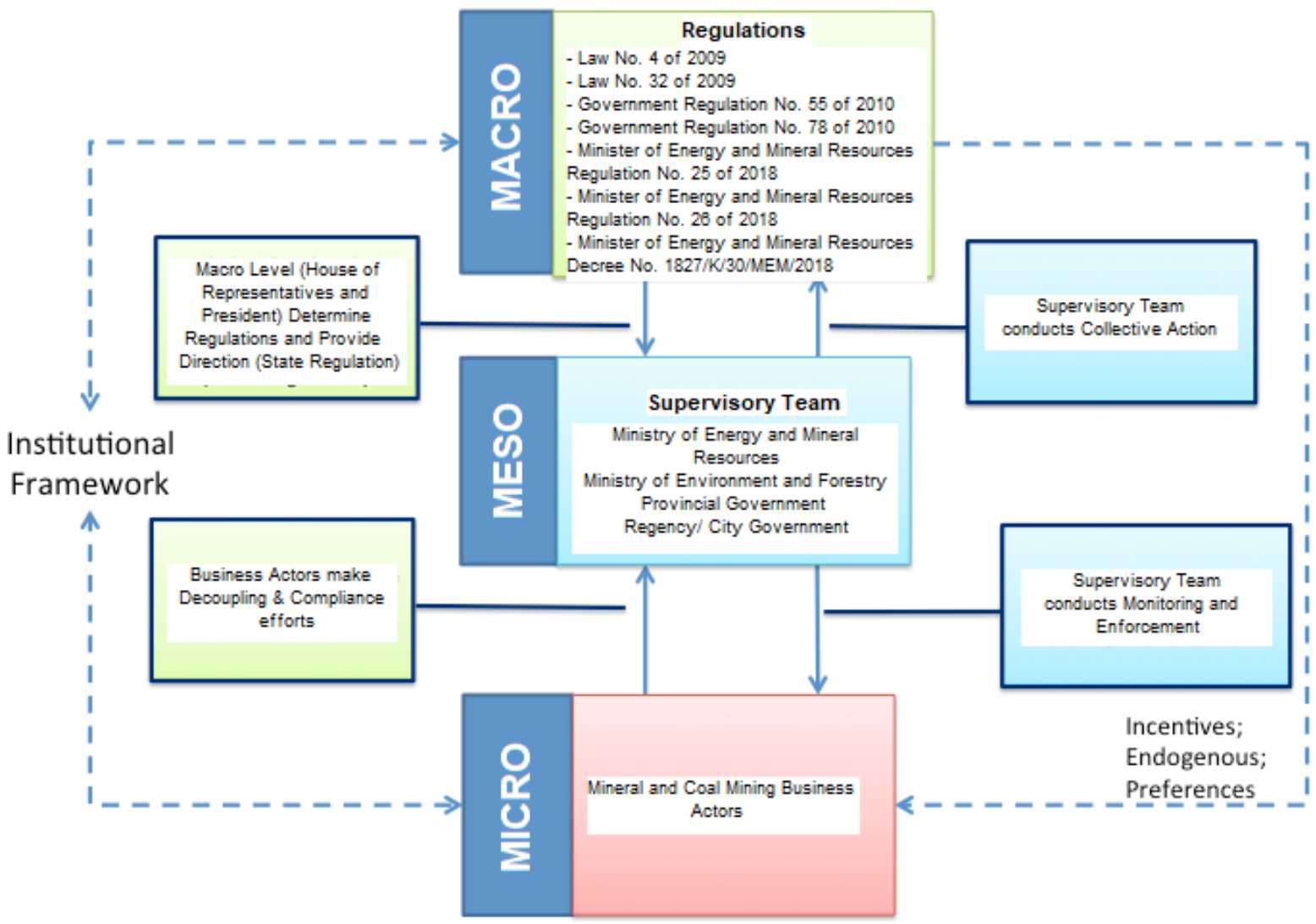

Figure 2. Existing Model of Reclamation \& Post-Mining Supervision System

At the Macro level, there are regulations governing reclamation and post-mining supervision. At the Meso level, there is a reclamation and post-mining Supervisory Team that conducts collective action and monitoring \& enforcement. At the Micro level, there are business actors who try to avoid decoupling by interacting and transacting between business actors, and are required to comply with various provisions determined by the government. 
The existing model of reclamation and post-mining supervision is not optimal in the process that leads to sustainable development. It refers to various analyzes conducted on findings in the practice of reclamation and post-mining supervision. There are some changes that are expected to produce a more effective and efficient mechanism for reclamation and post-mining supervision. Therefore, it can realize a sustainable development. The expected changes are found at all levels consisting of Macro, Meso, and Micro levels.

Law No. 4 of 2009 concerning Mineral and Coal Mining was once discussed in the House of Representatives of the Republic of Indonesia. In the previous planning, Revision of Law No. 4 of 2009 concerning Mineral and Coal Mining will overhaul a number of provisions, including incentives that can be obtained by mining companies.

In the Mineral and Coal Law Draft, there are several articles that have changed drastically. In article 47, Mining License for Production Operations, which are integrated with smelters or power plants, can be given an extension directly for a maximum of 20 years and can be extended for 10 years. In addition, in article 103, holders of a Mining License or Special Mining License, which carries out their own processing and refining and constructing power plants, can be given fiscal and non-fiscal incentives. One of them is not affected by a reduction in the area when getting permission to extend operations.

Furthermore, in article 169B, Contracts of Work (CoW) and Coal Mining Concession Work Agreements (PKP2B) which have been amended and integrated with smelters or power plants can be reoperated in the form of Special Mining License for a period of 20 years and can be extended 2x10 years. The area is also in accordance with the work plan of all mining areas that have been agreed in the contract. It means that there will be no reduction in territory.

Related to processing and refining, the holder of the CoW is obliged to carry out processing and refining no later than 2 years from the enactment of this Law. Then, the CoW, Mining License, and Special Mining License that have built or are building a smelter can sell a certain number of processed products abroad within a period of 2 years at the latest since this Law is enacted. Related to the divestment problem of at least $51 \%$, article 112 no longer specifically stipulates the time period for the release of shares. However, for those who build smelters or power plants, it is specifically regulated that the implementation of the divestment obligation starts within 10 years of the mining activities.

For deposits to the central government, it is planned that there will be an increase as stipulated in article 129 of the Mineral and Coal Bill. The central government which initially received $4 \%$ of net profits since production will receive 5\%. Local government revenue is also planned to increase from 6\% to $10 \%$. The $10 \%$ is divided into provincial governments by $4.5 \%$, regency/ city governments by $3.5 \%$, and other regency/ city governments in one province by $2 \%$.

Moreover, the contents of the Mineral and Coal Law Draft covers matters that are more detailed than the current Mineral and Coal Law. That includes the inclusion of Mineral and Coal Holding, procedures for determining mining areas, to changes in authority from the city/ regency government to the provincial government that uses the general term as regional government. In terms of discussions to revise the Mineral and Coal Law, related to the theme of this study, proposals for strengthening the monitoring system will be relevant if there is a process of further discussion. The existence of the Mineral and Coal Law that strengthens the monitoring system, the basis of its implementation is also strong. Meanwhile, when discussing the revision of the Mineral and Coal Law, it was considered to be stagnant and not urgent, the government then circumvented it by issuing Minister of Energy and Mineral Resources Regulation No. 25 of 2018 concerning Exploitation of Mineral and Coal Mining. 
Another recommendation for the restructuring of reclamation and post-mining supervision is to strengthen coordination between the supervisory team (relevant agencies that have the role of supervising). The status of the Supervisory Team can change to the Mineral and Coal Mining Supervisory Agency if necessary. This change in status is desirable so that mineral and coal mining supervision, which regulates reclamation and post-mining supervision, is more effective. The status of the Regulatory Agency is expected to be directly under the Ministry of Energy and Mineral Resources. Thus, responsibility for supervision is directly under the authority of the Minister. It is expected that the bargaining power of the Regulatory Agency will be stronger than its status only as a Supervisory Team.

Changing the status of the Supervisory Team to a Supervisory Agency which is directly under the Minister is very possible to be carried out simultaneously with the revision of the Mineral and Coal Law. This is intended as a form of strengthening the surveillance system in the field of mineral and coal mining. The law can bring up the article which states that the supervisory authority is under the authority of the Regulatory Body which is directly responsible to the minister. To elaborate on the duties, responsibilities, authority, etc. of the Supervisory Agency, it can bring up a paragraph stating that further provisions regarding this Supervisory Body are regulated in a Government Regulation.

The change in status of the Supervisory Team to the Supervisory Agency is a renewal of the structure and governance of mineral and coal mining supervision which also regulates reclamation and post-mining supervision. Due to the Supervisory Agency status, supervision is expected to be more effective and efficient. The following figure shows the reform structure and governance of supervision which is one of the proposed changes expected from the results of this study.

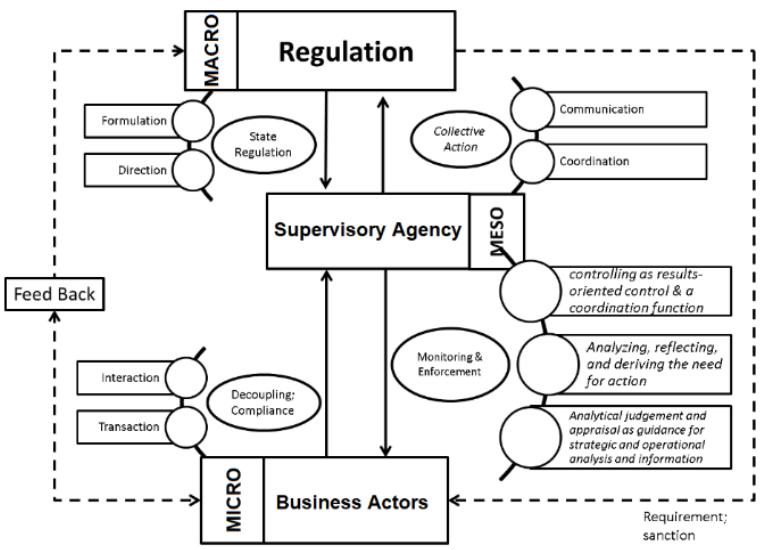

Figure 3. Renewal of Supervision Structure and Governance

The change in status of the Supervisory Team to the Supervisory Agency is expected to make a significant contribution to supervising interactions and transactions involving business actors. Therefore, they will avoid decoupling and increase compliance. In practice in the field, there are issues that need attention due to interactions and transactions between mining material businesses. It is because these interactions and transactions have the potential to cause fairly high decoupling actions.

Attention in this regard is to tighten supervision from the authorities regarding interactions and transactions between mining businesses. It is because the practice of interaction and transactions between these business actors contains quite high decoupling. Decoupling can also occur at the stage where reclamation and post-mining should have been carried out.

Moreover, in order to reorganize reclamation and post-mining supervision, another proposed recommendation is to increase the quantity and quality of supervisors (mine inspectors). This 
recommendation is very desirable because in addition to being small in number, the capacity of supervisors in conducting supervision also still needs to be improved. After increasing the capacity of supervisors, the monitoring process will be effective. As a result, the provisions relating to reclamation and post-mining can be obeyed by business actors in carrying out their business activities.

Desires related to increasing the capacity of supervisors should be easily realized. That is because the current policies are very supportive of the capacity building of supervisors. In fact, the policy emerged from the highest leader of the state, the President of the Republic of Indonesia. After the President of the Republic of Indonesia established a policy of mental revolution, it gave positive meaning to efforts to increase the capacity of supervisors. In addition, the government is also focused on realizing bureaucratic reform policies. One aspect targeted by bureaucratic reform is apparatus resource reform. In other words, if there is an effort to increase the capacity of supervisors, it is in accordance with the bureaucratic reform policy that is being intensively carried out by the government.

The capacity building of supervisors can be carried out in various ways. One possible way is to provide a variety of training that can improve the skills and knowledge of supervisors in conducting supervision. Thus, supervisors can provide solutions to various problems that arise during the supervision process.

The final recommendation expected in the context of restructuring supervision is to strengthen the role of business actors/ associations of business actors. Business actors/ associations have a strategic role in supporting the implementation of effective supervision. Association is a collection of business actors that can be a means of socializing various regulations established by the government. In this case, the government can hold meetings, communicate and coordinate with associations in order to disseminate various stipulated provisions. Furthermore, the association can be carried out through meetings with business actors who incidentally are members. It aims to continue various information obtained from the results of socialization conducted by the government.

In addition, the association may act as a "bridge" between business people and the government. For business people, the association can be a means to convey aspirations. For the government, due to the role of the association as an aspirant, it can sustain the implementation of open government by opening the widest opportunity for stakeholders to provide various inputs. Finally, the implementation of various government regulations can be effectively implemented by the government itself and voluntarily obeyed by business actors.

Some of the expected changes above are a form of the nature of research oriented to problemsolving interest. Complex monitoring problems can be anticipated by the formulation of some of the expected changes above. With the formulation of the expected changes, which incidentally covers all levels including Macro, Meso, to Micro, the revitalization of supervision can be achieved. As a result, it can create effective supervision.

\section{Conclusions}

1. Mining License and Special Mining License holders place reclamation guarantee funds in advance in accordance with the work plan and annual budget of a maximum of 30 days after the work plan is approved. Furthermore, funds are placed at state banks in the form of time deposits on behalf of the Directorate General/ Governor in accordance with the reclamation schedule. 
2. The implementation of reclamation and post-mining supervision is still not optimal because the readiness of supervisors is inadequate to conduct supervision activities with a limited number of supervisors.

3. The establishment of a supervisory agency is needed to strengthen their authority to conduct supervision.

\section{Suggestions}

Based on the above conclusions, this research proposes a number of recommendations which were actually mentioned to in the previous section. Here are some recommendations that can be submitted:

1. Update data on placement of reclamation and post-mining guarantee funds.

2. Increase the quantity and quality of mining supervisors or inspectors, and strengthen the association's role of mining business actors so that it becomes a bridge of compliance with the implementation of reclamation and post-mining by business actors.

3. Revise the Law on Mineral and Coal Mining, one of which discusses the Supervisory Agency.

4. Establish a supervisory agency to strengthen supervisory authority specifically to supervise mineral and coal mining. It is expected to further maximize reclamation and post-mining activities to ensure the preservation of the environment.

\section{References}

Bisnis.com, 2018. Reclamation \& Post-Mining Guarantees Are Still Low. Accessed from https://ekonomi.bisnis.com/read/20180114/44/726374/jaminan-reklamasi-pascatambang-masihrendah

CNBC Indonesia, 2018. Wow! Inalum Mineral and Coal Reserves are IDR 6,528 trillion. Accessed from https://www.cnbcindonesia.com/news/20180605100554-4-17862/wow-nilai-cadangan-mineraldan-batu-bara-inalum-rp-6528-t

Dye, Thomas R. 1975. Understanding Public Policy, Printice-Hall 2nd ed, Englewood Cliff, N. J., page 34

Eyeston, Robert. 1971. The Threads of Policy: A Study in Police Leadership, Bobbs Merril, Indiana Polis, page 112 .

F. Sugeng Istanto, 2007. Legal Research, CV Ganda, Yogyakarta, page 29., quoted from Saldi Isra, 2009. Shifts to the Legislative Function in the Indonesian Government System After Amendment to the 1945 Constitution, Dissertation for Postgraduate Program, Faculty of Law, Gadjah Mada University, Yogyakarta, page 141, in Saldi Isra, 2014. Recruitment and Appointment System of Supreme Court Justices and Constitutional Justices in the Conception of the Rule of Law, Research on the National Legal Development Agency (BPHN) in 2014, Jakarta, page 10. 
Ménard, Claude, 2004. The Economics of Hybrid Organizations, Journal of Institutional and Theoretical Economics (JITE)/Zeitshrift für die gesamte Staatswissenschaft, Vol. 160, No. 3, page 345-376.

Ménard, Claude, 2004. The Economics of Hybrid Organizations, Journal of Institutional and Theoretical Economics (JITE)/Zeitshrift für die gesamte Staatswissenschaft, Vol. 160. No. 3, page 345-376.

Ministry of Environment and Forestry, 2018. Light up the Post-Mining Land in Bangka Belitung Province. Accessed from http://www.menlhk.go.id/berita-10841-hijaukan-lahan-pascatambang-di-provinsi-bangka-belitung.html

Mongabay, 2018. Walhi: Indonesia's Condition is Still in an Ecological Emergency. Accessed from https://www.mongabay.co.id/2018/04/24/walhi-kondisi-indonesia-masih-darurat-ekologis/

Nee, Victor, 2003. The New Institutionalism in Economics and Sociology. Center of Study Economy and Society, Vol. 4, page 3

Peter Mahmud Marzuki, 2007. Legal Research, CV. Ganda, Yogyakarta, 3rd Print, Pranada Media Group, Jakarta, page 137

PT ANTAM, 2016. Biodiversity. Accessed from $\mathrm{http}: / / \mathrm{www}$. antam.com/index.php?option=com_content\&task=view\&id=428\&Itemid=211\&lang $=\mathrm{i}$

Soerjono Soekanto, 2007. Factors Affecting Law Enforcement, Publisher PT Raja Grafindo Persada, Jakarta, page 10 .

Tempo, 2018. Reclamation of Mining Pit. Accessed from https://kolom.tempo.co/read/1094037/reklamasi-lubang-sisa-tambang/full\&view=ok.

Williamson, Oliver E. 1975. Markets and Hierarchies: Analysis and Antitrust Implications, The Free Press, New York, page 28.

Winarno, Budi. 2005. The Theory and Process of Public Policy, Medpress, Yogyakarta, page 20.

\section{Copyrights}

Copyright for this article is retained by the author(s), with first publication rights granted to the journal. This is an open-access article distributed under the terms and conditions of the Creative Commons Attribution license (http://creativecommons.org/licenses/by/4.0/). 